\title{
Microhabitat utilization and population density of the lizard Gonatodes humeralis (Guichenot, 1855) (Reptilia: Squamata: Gekkonidae) in forest areas in Manaus, Amazon, Brazil \\ Utilização de microhabitats e densidade populacional do lagarto Gonatodes humeralis (Guichenot, 1855) (Reptilia: Squamata: Gekkonidae) em áreas de floresta na região de Manaus, Amazonas, Brasil
}

\begin{abstract}
Gonatodes humeralis is a small lizard widely distributed in Amazonia and found on tree trunks. An increase in its abundance in deforested areas has been observed in several studies, although the factors causing this increase remain unknown. In this study, population density was estimated in forests in different stages of regeneration. Population densities and habitat characteristics were analyzed by multiple regression. This analysis showed that population density was positively related to the number of available trunks and negatively related to forest regeneration stage. Analysis of microhabitats used by G. humeralis was made to evaluate whether the species selects the tree trunks it uses. This selection has been reported for arboreal lizards, although only diameter was quantified. Comparison between the frequency distributions of used and available trunks showed that $G$. humeralis did not select trunks either by circumference or by canopy density. However, amount of leaf litter and trunk rugosity were used in different proportions relative to the available, suggesting that this species prefers trunks with intermediate rugosity and less leaf litter around it. This selection may be related to ease of movement between trees, while the selection of trunks with intermediate surface rugosity may be related both to lizard mobility and predator avoidance. Additional studies would show whether these patterns are also found in other populations.
\end{abstract}

Keywords: Squamata. Gonatodes humeralis. Habitat utilization. Population density. Deforestation.

Resumo: Gonatodes humeralis é um pequeno lagarto encontrado em troncos de árvores por toda a Amazônia. Aumentos em sua abundância, em áreas alteradas, foram observados em diversos estudos, embora os fatores responsáveis pelos aumentos permaneçam desconhecidos. Neste estudo, sua densidade foi positivamente relacionada com número de troncos disponíveis e negativamente relacionada com o estágio de regeneração da floresta. A análise dos microhabitats usados foi feita para avaliar se esta espécie seleciona os troncos que utiliza, pois há registros de lagartos arborícolas que o fazem, embora somente o diâmetro tenha sido quantificado. Para descrever microhabitats usados, foram registrados: circunferência e rugosidade dos troncos e, ao redor dos mesmos, espessura da serapilheira e densidade da copa. Estas mesmas características foram registradas para uma amostra de troncos disponíveis. Comparações entre distribuições de freqüência dos troncos disponíveis e utilizados mostram que $G$. humeralis não seleciona troncos por circunferência ou densidade da copa. Entretanto, rugosidade dos troncos e quantidade de serapilheira ao seu redor foram usados em proporções diferentes do que havia disponível, sugerindo que prefere troncos com rugosidade intermediária e menos serapilheira ao redor. Além da facilidade de locomoção entre troncos, a escolha de pouca serapilheira pode indicar que esteja evitando predadores, enquanto a seleção de troncos com rugosidade intermediária pode relacionar-se tanto com locomoção quanto com detecção de predadores. Estudos adicionais poderiam mostrar se estes padrões podem também se apresentar em outras populações.

Palavras-chave: Squamata. Gonatodes humeralis. Utilização do ambiente. Densidade populacional. Deflorestamento.

\footnotetext{
Universidade Federal do Amazonas. Manaus, Amazonas, Brasil (yoda@ufam.edu.br).
}

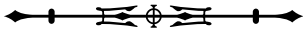




\section{INTRODUCTION}

Gonatodes humeralis is a small, cryptic colored, diurnal lizard (maximum snout-vent length $41 \mathrm{~mm}$ ) that exhibits sexual dimorphism. Males are brighter than females and present a predominantly grey coloration with yellow and crimson variably shaped spots on the head (Figure 1); females have a light brown coloration, with dark brown spots (Figure 2) (Vanzolini, 1968; Ávila-Pires, 1995). Both sexes have a white, vertical antehumeral line, preceded by a black spot. This species occurs primarily in forest (Vanzolini, 1972), occupying edges of forests, the interior of primary and secondary forests (Vitt et al., 1997, 2000; O'Shea, 1989), plantations (Vanzolini, 1972) and perianthropic areas (Vanzolini, 1986; Duellman, 1987).

The species generally lives on the lower portions of tree trunks and vines (Vitt et al., 2000) with $20-40 \mathrm{~cm}$ circumference (e. g., Nunes, 1984; Vittet al., 1997) at a mean height of nearly $70 \mathrm{~cm}$ (Nunes, 1984; Vitt et al., 2000) and rarely higher than $1.5 \mathrm{~m}$ (O'Shea, 1989; Vanzolini, 1972, 1986). G. humeralis also lives in leaf litter, fallen branches, trunks and palm leaves (Gasc, 1990; Vitt et al., 1997).

Although the main habitats that it exploits are known, there is uncertainty about the occupation of disturbed areas. Several studies suggest an increase in the abundance of $G$. humeralis in secondary forests (Rand \& Humphrey, 1968; Dixon \& Soini, 1975; Nunes, 1984; O'Shea, 1989; Cunha et al., 1985; Duellman, 1987; Gasc, 1990). Inside primary forest, Dixon \& Soini (1975) found the species to be more abundant in clearings. The authors found this species also occupying walls of human habitations.

On the other hand, some studies suggested that $G$. humeralis occurs mainly in primary forest (Crump, 1971; Vanzolini, 1986). Vittet al. (1997) registered a larger number of individuals in primary forest, or primary forest and forest edge, than in secondary forest, in two Amazonian localities. Conversely, they observed a population occupying exclusively human made constructions in a third locality, in Ecuador, and suggested that this population could represent a recent introduction by humans.
In spite of the contradictory information about habitat utilization by this species, few efforts have been made to produce quantitative data about populations in disturbed areas, because the majority of the studies evaluated natural populations in primary forests. Disturbed areas are considered to have little importance in animal conservation. However, large disturbed areas are common and some of them are capable of supporting a number of species that are not able to survive in isolated and small reserves (Johns, 1985).

This study attempts to identify some of the environmental factors that affect population density in $G$. humeralis in disturbed habitats. Specifically, it tries to answer the following questions: Does disturbance affect population density of $G$. humeralis? Does the species show preference regarding circumference and rugosity of trunks and the canopy density of the trunks that it uses? Is the amount of leaf litter surrounding the trunks an important factor in the choice of the trunks?

\section{MATERIALS AND METHODS}

Field Sites: The study was conducted at twelve different sites in the city of Manaus and surroundings, Amazonas state, Brasil, representing six primary and six secondary forests in different stages of regeneration (Figure 3). The following urban areas were studied: Campus of "Universidade Federal do Amazonas" (UFAM; two sites), "Mindu” Municipal Park (one site), and "Clube do Trabalhador" (SESI; one site) forested areas outside the city limits included the Adolpho Ducke reserve of the "Instituto Nacional de Pesquisas da Amazônia" (INPA; one site), the Experimental Farm of UFAM (two sites), and reserves of the INPA - World Wildlife Fund (INPA/ WWF; five sites).

A detailed description of the sampled areas is given below:

Campus of UFAM: Two secondary forest areas were sampled at this location. One S 3०4'34" W 59057'30" was an old secondary forest with 20-30 years of regeneration (M. C. Silva, personal communication).

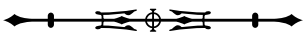




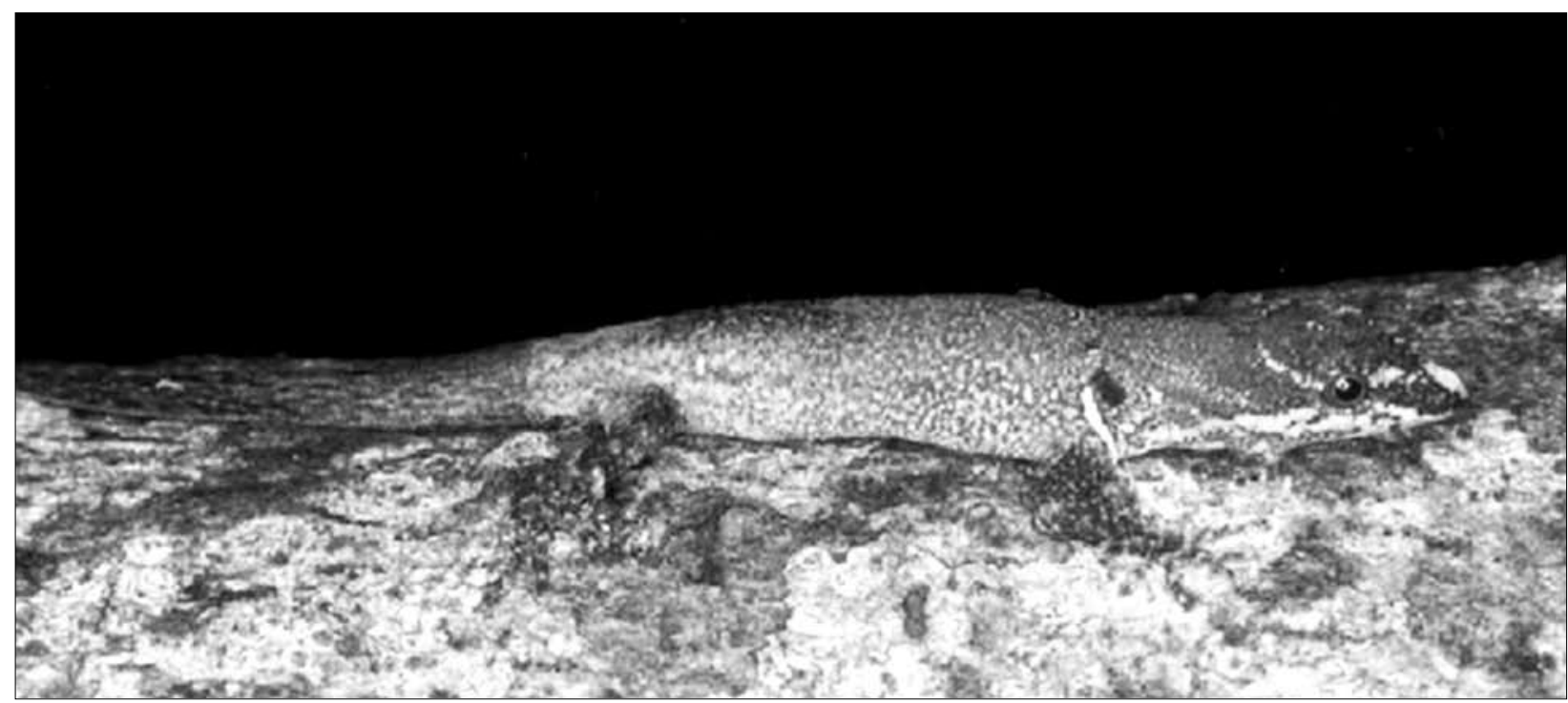

Figure 1. Gonatodes humeralis (male) found on Campus of UFAM, Manaus, AM. Foto: Marcelo Gordo.

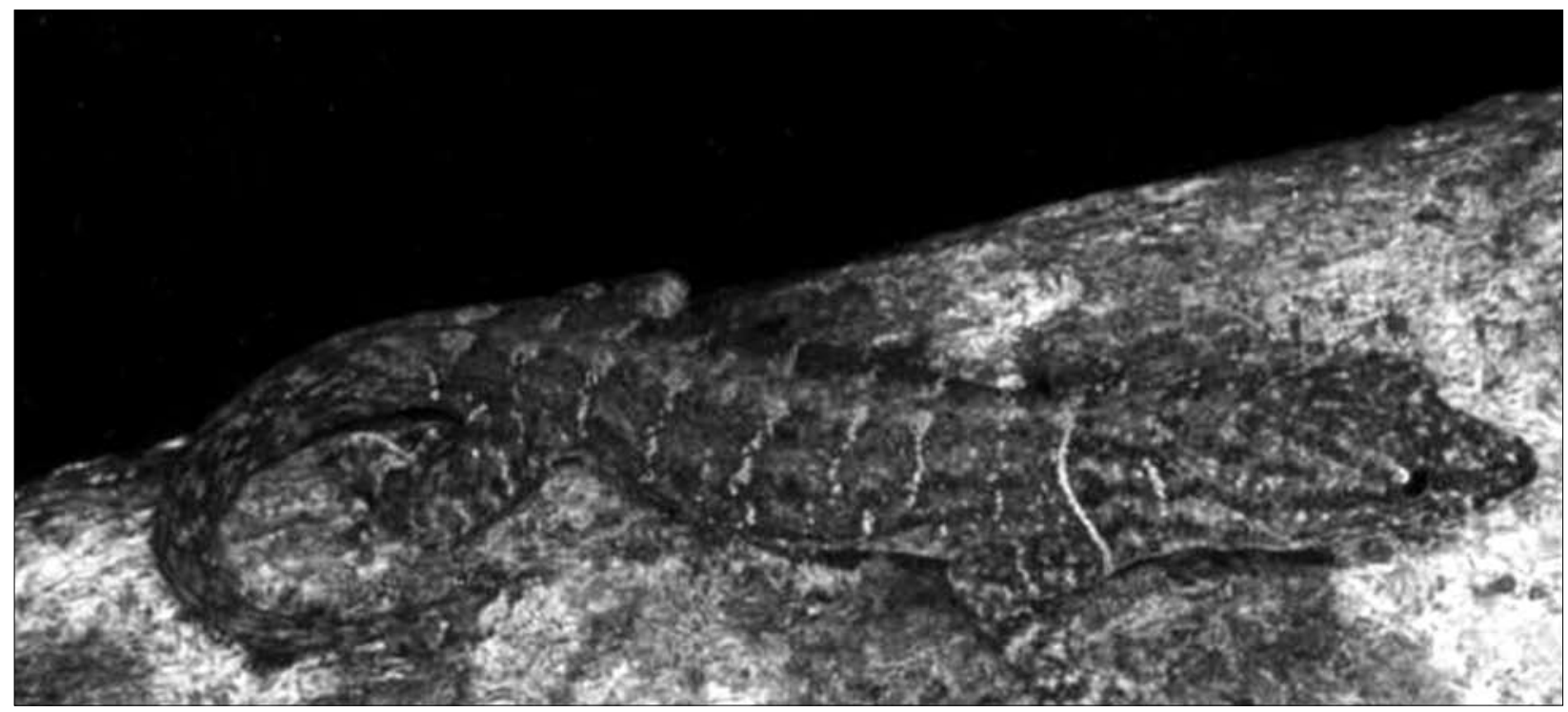

Figure 2. Gonatodes humeralis (female) found on Campus of the UFAM, Manaus, AM. Foto: Marcelo Gordo.

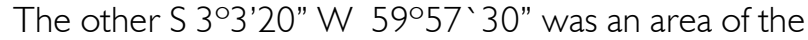
same regeneration age which had suffered less impact during the deforestation and it had an almost intact canopy of large trees.

"Mindu" Municipal Park: This area consists of 30 ha of secondary forest, located at S 3०8'56" W 600'39" in urban zone, dominated by Cecropia spp. Mean height of trees is $11 \mathrm{~m}$.

"Clube do Trabalhador" (SESI) Located in S $3^{\circ} 6^{\prime} 00^{\prime \prime}$ W 59 58'30". About a half of this 10 ha is covered with a vegetation composed of bushes and grass that are $2.5 \mathrm{~m}$ high, while the other half contains taller vegetation

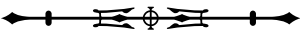




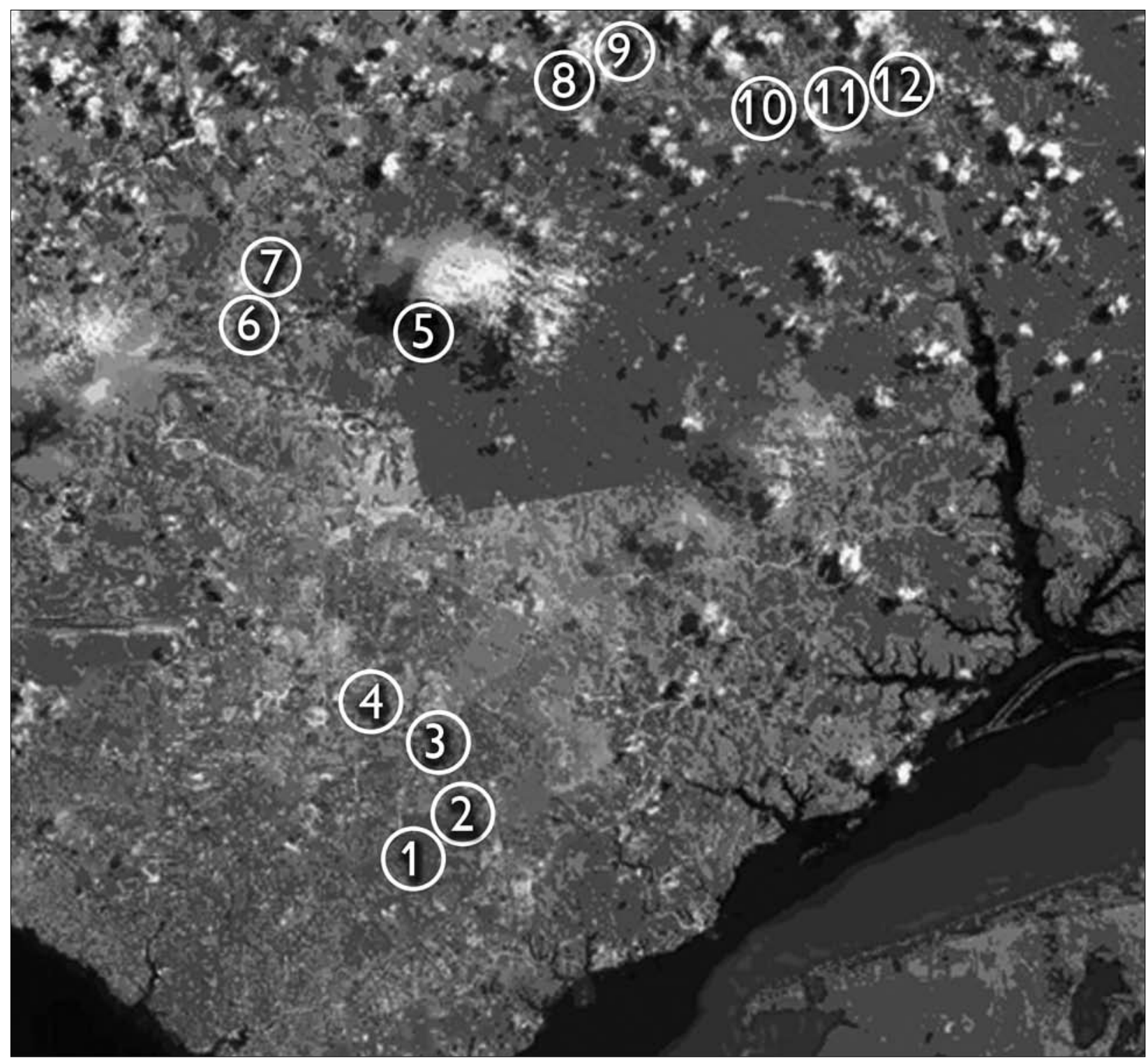

Figure 3. Map of Manaus region, showing the study areas. (1-2) Campus of "Universidade Federal do Amazonas (UFAM)", (3) "Clube do Trabalhador" ("SESI"), (4) "Mindu" Municipal Park, (5) Adolpho Ducke reserve, (6-7) Experimental farm of "UFAM", (8-12) PDBFF reserves. Image from the archives of PDBFF/INPA.

that grew after burning (mainly palms), with an understory of sparsely distributed bushes and grasses.

Adolpho Ducke reserve (INPA): Located at Km 26 of the Manaus-Itacoatiara (AM-10) road, the reserve is covered by 10.000 ha of dense "terra firme" primary forest which is not subject to seasonal flooding. Mean height of trees is close to $40 \mathrm{~m}$. Only one plateau primary forest area (S $3^{\circ} 4^{\prime} 0^{\prime \prime}$ W 59 56 $\left.6^{\prime} 0^{\prime \prime}\right)$ was sampled at this reserve.

Experimental Farm of UFAM: Located at Km 35 of Manaus-Presidente Figueiredo (BR-174) road and covered by an old secondary forest with a height similar to the adjacent primary forests. At several points in this forest it is possible to observe selective logging. However,

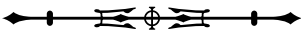


we sampled only two areas (S 2047'5" W 60'11'51" and S 2०45'38" W 60'1'26"), without selective logging. The vegetation in these sample units was 30 to $35 \mathrm{~m}$ in high.

Biological Dynamics of Forest Fragments Project (PDBFF) reserves: This area is composed of several reserves that consists of isolated portions of continuous "terra firme" forest marked for future protection or actual protected forest fragments. The forest canopy reaches a height of nearly $40 \mathrm{~m}$ and palms dominate the under story (Bierregaard et al., 2001) Three different areas in $\mathrm{Km}$ 41 reserve at road ZF-3 road (S 2020'30" W 60'6'22",

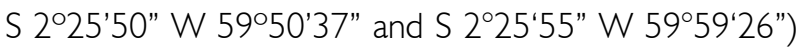
and two areas at Gavião Farm, located at Km 18 of the same road were sampled (S 60²'26" W 2'23'32"), all representing primary forests.

Methods: Field observations were conducted from March to June 1998. Since they were made in months with similar rainfall, we assumed that rainfall did not influence our results.

At every field site, sampling was conducted by walking along $1.5 \mathrm{~km}$ trails observing lizards. Each trail was sampled only once in a three hour period. To standardize search effort and time of the day these trails were walked from 09:00 to 12:00 AM. To reduce topographic effects, field sites were selected only at plateau areas.

Lizards were caught manually, measured, weighted and released at the same site. For quantification data about habitat utilization, for each lizard caught we also recorded: hour, height relative to soil, sex, tree trunk circumference at $50 \mathrm{~cm}$ from soil level (using a metric flexible tape), trunk rugosity, the amount of leaf litter around the trunk (using a graduated stick) and canopy density above the trunks utilized by the lizards. Canopy density was measured using a spherodensiometer, which estimated the percentage of light that passed through the vegetation to the soil using a concave mirror milimetrically graduated. The spherodensiometer was positioned at soil level, as close as possible to the capture site. The rugosity was estimated by comparing the relief of trunk surfaces obtained by making a print rubbing a paper with a pencil, against the tree trunk. These samples were categorized in ten rugosity degrees (Figure 4). To investigate the characteristics of trunks available in the environment, trunks were sampled along the trails in the field sites. At the first $100 \mathrm{~m}$ of each trail, we measured one of each ten trunks with circumference larger than $10 \mathrm{~cm}$ and the trunk of each tree where we found lizards. We included trunks of dead trees that were in a vertical position in the sample. Height of the vegetation, used as an estimate of forest regeneration stage, was measured along each $50 \mathrm{~m}$ of trail using a marked stick.

\section{Data ANALYsIS}

Population density in each area was estimated using number of individuals per kilometer of trail. Relation between population density and environmental variables were examined using a multiple regression analysis, where the independent variables were forest mean height, mean circumference and number of trunks sampled. Possible relations among variables were verified through a Pearson Correlation Matrix.

To examine habitat utilization we compared the circumference and rugosity of trunks, canopy density above trunks and amount of leaf litter around trunks utilized by Gonatodes humeralis versus available trunks in the areas. Frequency distributions of available and utilized trunks were compared through Two-Sampled Kolmogorov-Smirnov test.

\section{RESULTS AND DISCUSSION}

\section{Population Density}

Eighty-two individuals of $G$. humeralis were found in the twelve sampled areas (mean 4.56 individuals $/ \mathrm{km}$ of trail). Only 6 (7.3\%) were juveniles. Among the adults, 34 (44.7\%) were males and 39 (51.3\%) were females. In three cases (4.0\%), sex could not be established.

Regarding the type of forest (primary or secondary) occupied, 70 individuals (85.4\%) were found in secondary 


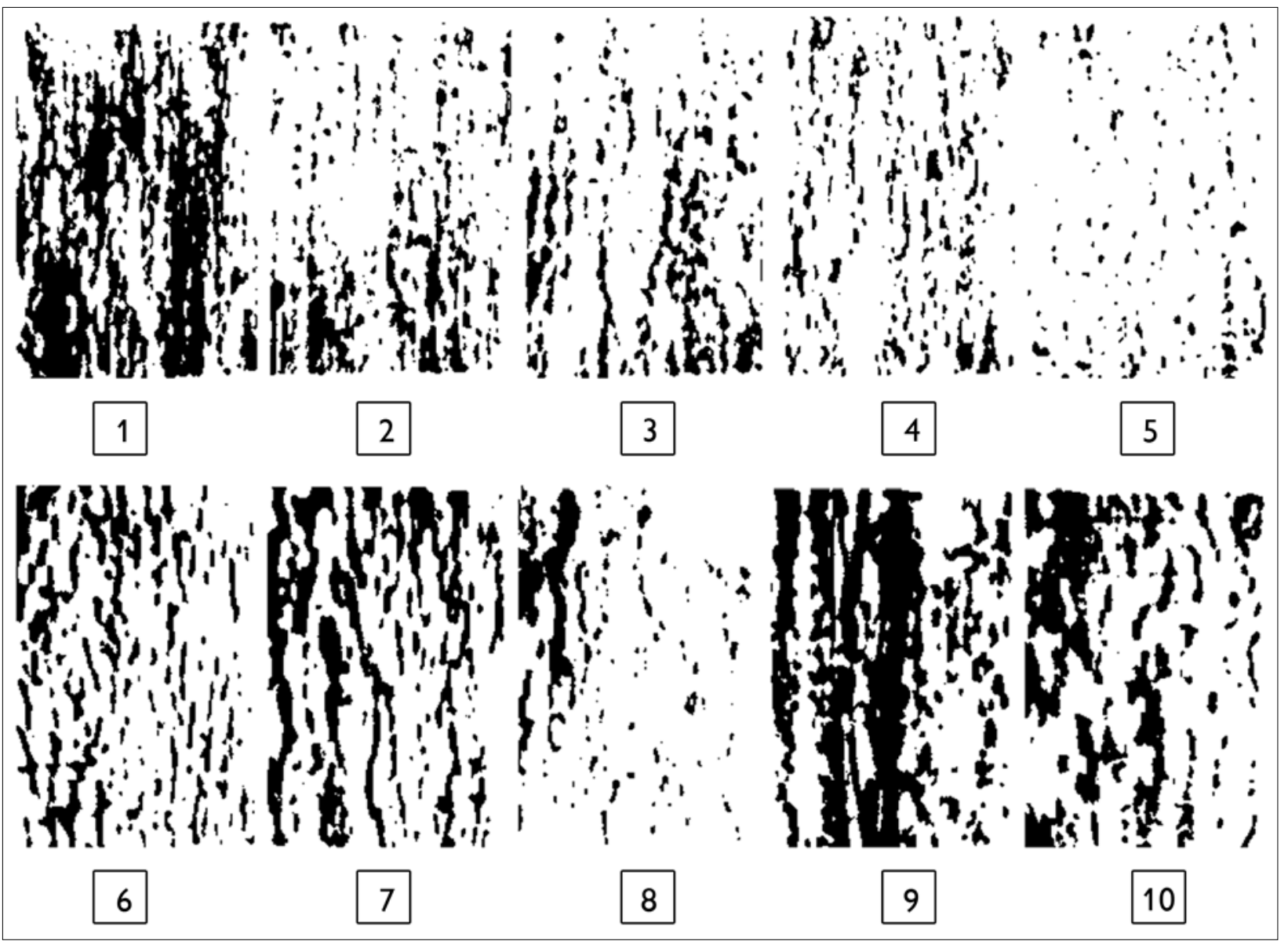

Figure 4. Prints of trunk surfaces, showing rugosity categories (rugosity increases from 1 to 10).

forest, at densities from 0.67 to 28.70 (mean 4.61) individuals/ $\mathrm{km}$ of trail, while 12 individuals (14.6\%) were found in primary forest, at densities from 0.7 to 2.0 (mean 1.33) individuals $/ \mathrm{km}$ (Table 1). Vitt et al. (1997), in contrast, observed this species mainly occupying primary forest.

Association of two factors - height of vegetation and trunk density - explains most of the variation in population density $\left(R^{2}=0.748, n=12, p=0.001\right)$. Multiple regression of these variables shows that $G$. humeralis density was positively correlated to the number of trunks and inversely correlated to the mean height of forest (Table 2).

The negative relationship between population density of $G$. humeralis and height of vegetation indicates that higher densities of the species occur at most disturbed areas.
However, the positive relationship between lizard density and the number of trunks indicates that colonization, and the consequent increase in population, seems to occur only several years after deforestation, when a considerable number of trees of appropriate size will be available.

\section{HABITAT UTILIZATION}

Gonatodes humeralis was primarily found occupying tree trunks ( $95.1 \%$ of occasions, $n=78$ individuals), being rarely observed in the following microhabitats: fallen trunk, buttresses, palm leaves and on leaf litter (4.9\% of occasions, $n=4$, being one juvenile, one female and two males). Except for three individuals (one juvenile, one male, one female) for which the height above the ground 
Table 1. Number of individuals and population density of $G$. humeralis in each studied area, according to forest type.

\begin{tabular}{|c|c|c|}
\hline Studied area & Number of individuals & Population Density $(\mathrm{n} / \mathrm{Km})$ \\
\hline \multicolumn{3}{|l|}{ Primary Forest Areas } \\
\hline Adolpho Ducke reserve & 2 & 1.33 \\
\hline 41 reserve area 1 & 2 & 1.33 \\
\hline 41 reserve area 2 & 2 & 1.33 \\
\hline 41 reserve area 3 & 2 & 1.33 \\
\hline "Gavião" Farm area 1 & 3 & 2,00 \\
\hline "Gavião" Farm area 2 & 1 & 0.67 \\
\hline \multicolumn{3}{|l|}{ Secondary Forest Areas } \\
\hline Experimental farm of "UFAM" area 1 & 1 & 0.67 \\
\hline Experimental farm of "UFAM" area 2 & 0 & 0 \\
\hline Campus "UFAM" area 1 (recent secondary forest) & 18 & 12.00 \\
\hline Campus "UFAM" area 2 (old secondary forest) & 8 & 5.33 \\
\hline "Mindu" Municipal Park & 42 & 28.70 \\
\hline "Clube do Trabalhador (SESI)" & 1 & 0.67 \\
\hline
\end{tabular}

Table 2. Multiple Regression of variables related to the population density of Gonatodes humeralis in Manaus region.

\begin{tabular}{lccc}
\hline \multicolumn{1}{c}{ Independent Variables } & Coefficient & T & Power (5\%) \\
\hline Trunk density $(n)$ & 1.446 & 5.171 & 0.99 \\
Mean height of forest $(\mathrm{m})$ & -0.454 & -3.976 & 0.94 \\
$\mathrm{R}^{2}=0.748 ; \mathrm{N}=12 ; \mathrm{F}=14.885 ; \mathrm{P}=0.001 ;$ Power $(5 \%)=0.847$ & & \\
\hline
\end{tabular}

was not available because they were disturbed and only seen moving, lizards (taking into account all specimens, independent of substrate) were found at different heights relative to the ground $(0-200 \mathrm{~cm}, \bar{x}=46.61 \pm 29.46$ $\mathrm{cm}, n=79$ individuals).

Regarding occupation of different available microhabitats, G. humeralis was found almost exclusively on tree trunks and only occasionally on other substrates, at similar proportions relative to other studies realized in Amazonia (Vitt et al., 1997, 2000).

Among the six juveniles, one was moving and had no height registered, and of the other five none was found higher than $50 \mathrm{~cm}$ from the ground, but a comparison with height distribution among adults $(0-200 \mathrm{~cm}$, median
$50.0 \mathrm{~cm}, \mathrm{n}=73$ ) did not show a significant difference (Kolmogorov-Smirnov $D_{74,5}=0.32, P=0.62$ ). Despite the low number of observations, juveniles were found at lower heights relative to adults and they were frequently observed between prop roots at the base of trunks. Utilization of portions of trunks close to the ground may indicate that these individuals prefer sites closer to hiding places. Preference of young lizards for lower heights, probably increased the difficulty of encountering them. This could explain why the majority of the individuals found in several studies were adults (Dixon \& Soini, 1975; Nunes, 1984; Martins, 1991; Vitt et al., 1997; this study).

Difference between sexes was also not significant (Kolmogorov-Smirnov $D_{38,33}=0.31$ e $P=0.28$ ). Males 
were found at heights from 10 to $200 \mathrm{~cm}$ (median 50.0 $\mathrm{cm}, \mathrm{n}=33$ ), while females were found from 0 to $110 \mathrm{~cm}$ (median $40.0 \mathrm{~cm}, n=38$ ) above ground (Figure 5).

Although the heights at which $G$. humeralis was observed on tree trunks was similar to that in general studies (e.g., Rand \& Humphrey, 1968; Vanzolini, 1972, 1986; Dixon \& Soini, 1975; Duellman, 1987; O'Shea, 1989; Martins, 1991), the heights observed in this study are different from the results reported in another detailed study involving this species. Vitt et al. (1997) observed this species from 0.3 to $4000 \mathrm{~cm}$ height in diverse Amazonian localities. In the same study, the authors, observing individuals in haphazard transects close to Curuá-Una, Pará, found this species occupying higher sites. The heights where this lizard was found in primary forest areas in the present study were lower than the heights found by Vitt et al. (1997). However, Vitt et al. (2000) found almost the same mean height in a population of "Parque Estadual Guajará-Mirim", in Rondônia State. Nunes (1984) observed this species in secondary forests at similar mean heights found by Vitt et al. (2000), but lower than the individuals founded in secondary forest in the present study. The results obtained here only relate to lizards found from 09:00 to 12:00 PM. As the height utilized varies significantly during the day (Nunes, 1984; Vitt et al., 1997), part of this variation was not observed in the present study. However, a comparison of the heights observed by Vitt et al. (1997) during the same period and the mean heights obtained in this study, shows that the results obtained by Vitt et al. (1997) are, in general, considerably higher.

\section{Circumference OF TRUNKS}

Except for one individual (male) found on a tree with a circumference close to $18 \mathrm{~m}$ (measured at $50 \mathrm{~cm}$ above ground, including buttresses), and four other individuals found in other microhabitats ( 1 juvenile on a fallen trunk, 1 female on leaf litter and two males (one on leaf litter, one on a palm leaf)), adults of $G$. humeralis used as substrate trunks

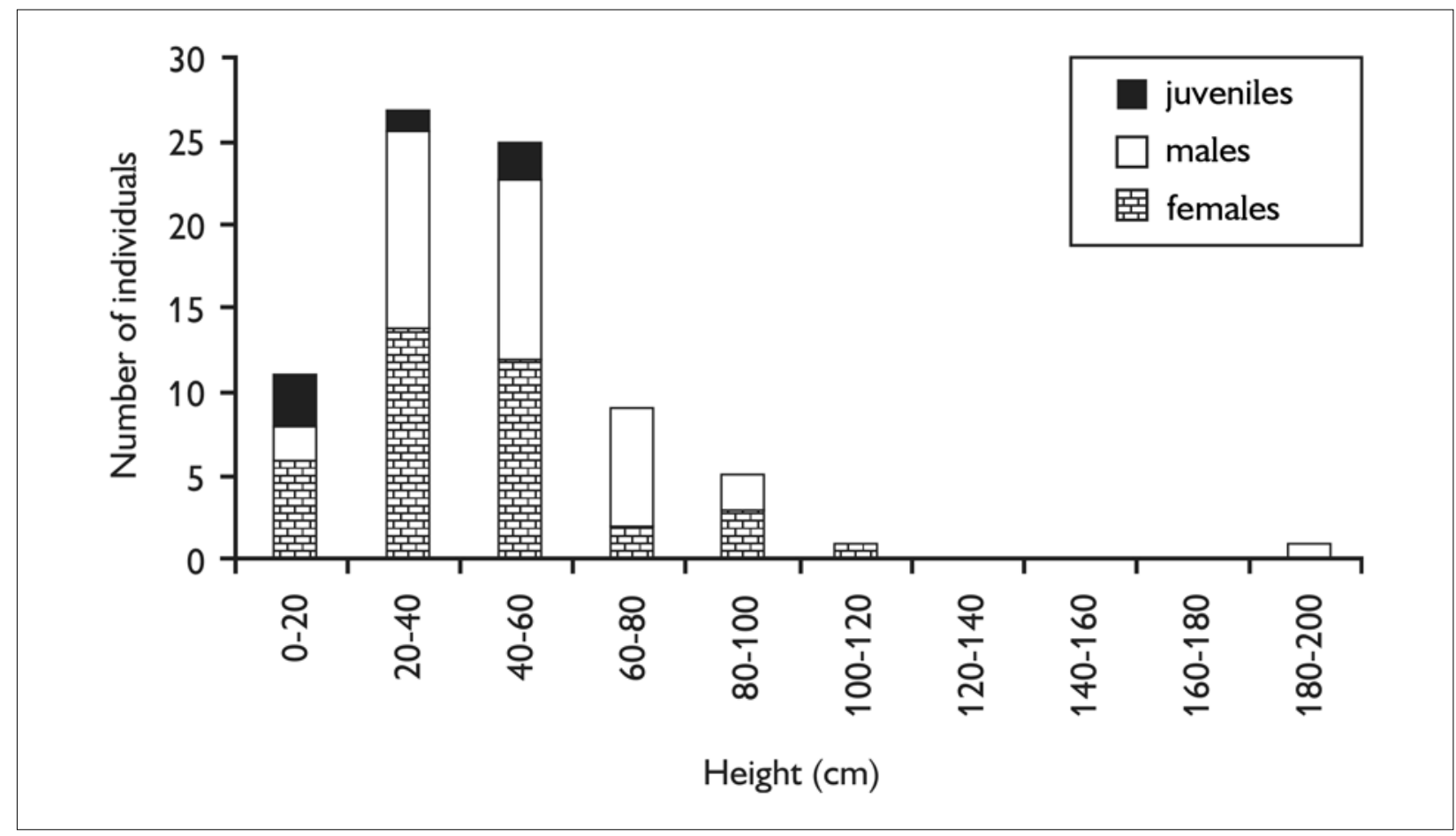

Figure 5. Distribution of height above ground of perch sites used by Gonatodes humeralis in the Manaus region.

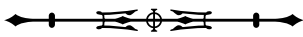


with circumference varying from 8.3 to $144.2 \mathrm{~cm}$ (median $30.0 \mathrm{~cm}, \mathrm{n}=72$ ). Juvenile individuals (one was found on the ground and not taken into account here) utilized a narrower circumference range $(13.9-23.2 \mathrm{~cm}, 17.5 \mathrm{~cm}, \mathrm{n}=4)$ relative to adults (8.3-144.2 cm, median $32.5 \mathrm{~cm}, \mathrm{n}=71$ ), but theses values did not differ significantly (Kolmogorov-Smirnov $D_{71,5}$ $=0.33, P=0.78)$. Neither did differences found between sexes (Kolmogorov-Smirnov $D_{38,30}=0.16, P=0.82$ ) (Figure 6). Circumference of trunks utilized in primary forest (8.4-90.2 cm, median $36.5 \mathrm{~cm}, \mathrm{n}=9$ ) ) was similar to those of trunks utilized in secondary forest $(8.3-144.2 \mathrm{~cm}$, median $32.0 \mathrm{~cm}, \mathrm{n}=69$ ).

Circumferences of trunks utilized by $G$. humeralis were not significantly different from those of available trunks (Kolmogorov-Smirnov $D_{69,140}=0.17, P=0.11$ ) (Figure 7) and it seems that $G$. humeralis does not select trunks on basis of light penetration in the forest, as indicated by canopy density above them (Kolmogorov-Smirnov $D_{69,140}=0.35$, $P=0.22)$ (Figure 8).
The circumferences observed here were also different from those observed by Vitt et al. (1997). This difference may be due to the fact that the majority of the lizards observed in this study lived in secondary forest areas, where the trees possess smaller circumferences in comparison to primary forest areas. When values found in this study are compared to the values that were observed by Vitt et al. (1997) in Curuá-Una, Pará, where the lizards were occupying disturbed areas, frequently utilizing poles of human buildings, the means are similar. Nunes (1984) found a preference of this species for trees that measured $30 \mathrm{~cm}$ in circumference, although she didn't show the mean circumference utilized.

Microhabitat selection by lizards that utilize tree trunks has been observed for some lizard species (Scott Jr., 1976; Nunes, 1984). However, trunk diameter was the only feature considered in these studies. Other trunk features may also be important for lizards. For example, trunks with very irregular surfaces can make movement difficult or make it difficult to

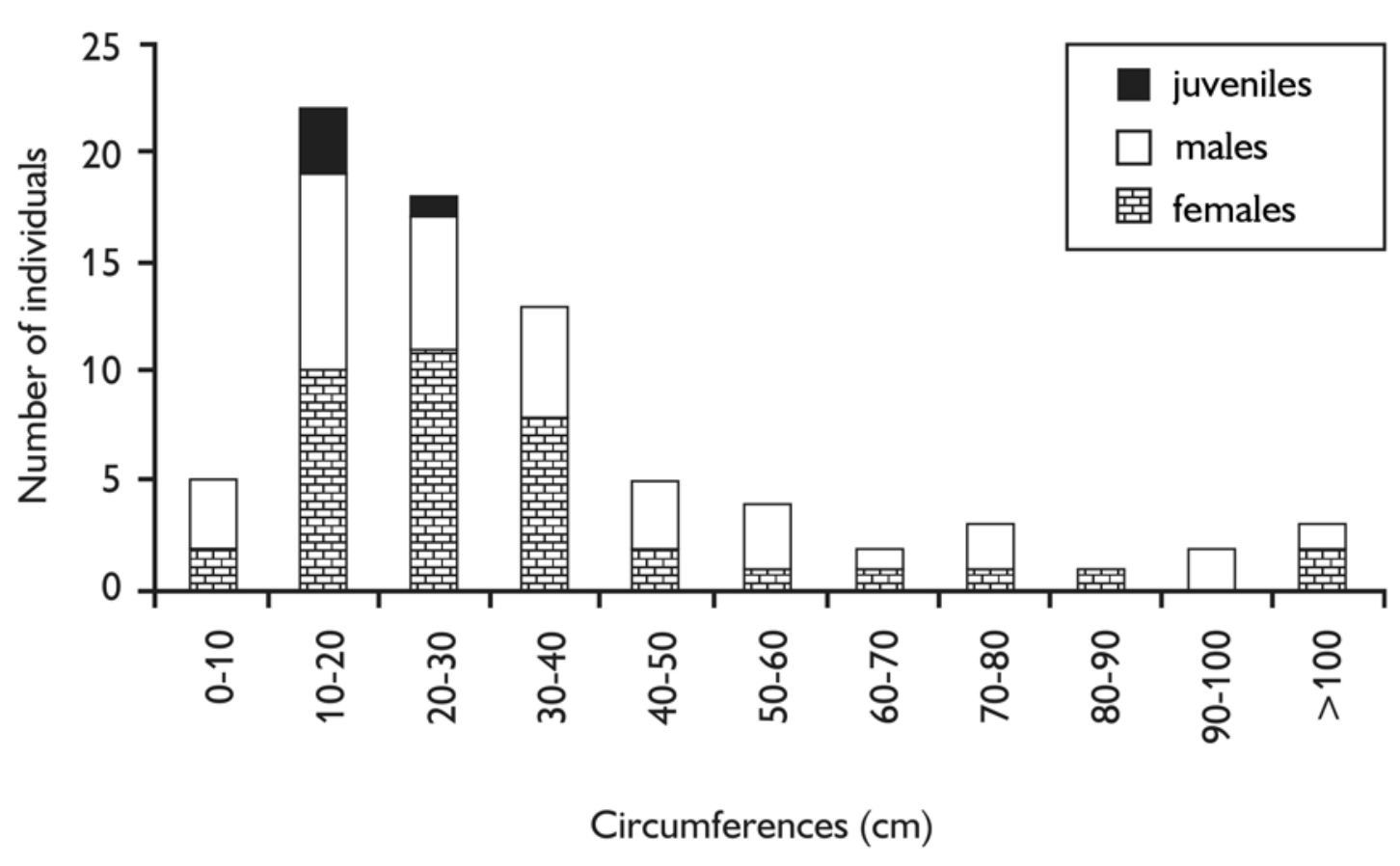

Figure 6. Circumferences of trunks utilized by $G$. humeralis in the studied sites.

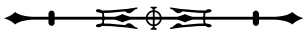




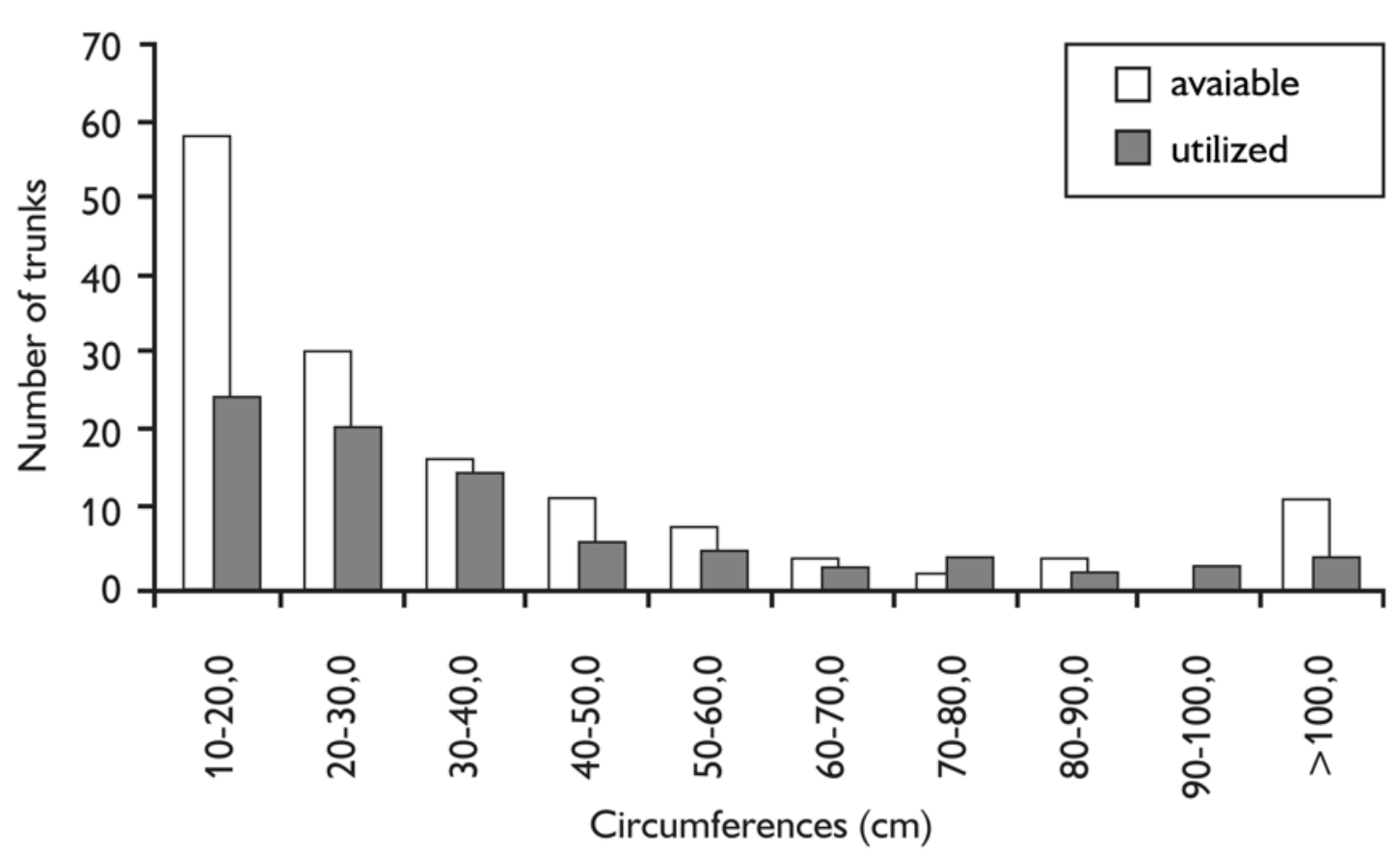

Figure 7. Relation between the circumferences of trunks utilized by G. humeralis and circumferences of available trunks in the forest in the studied sites.

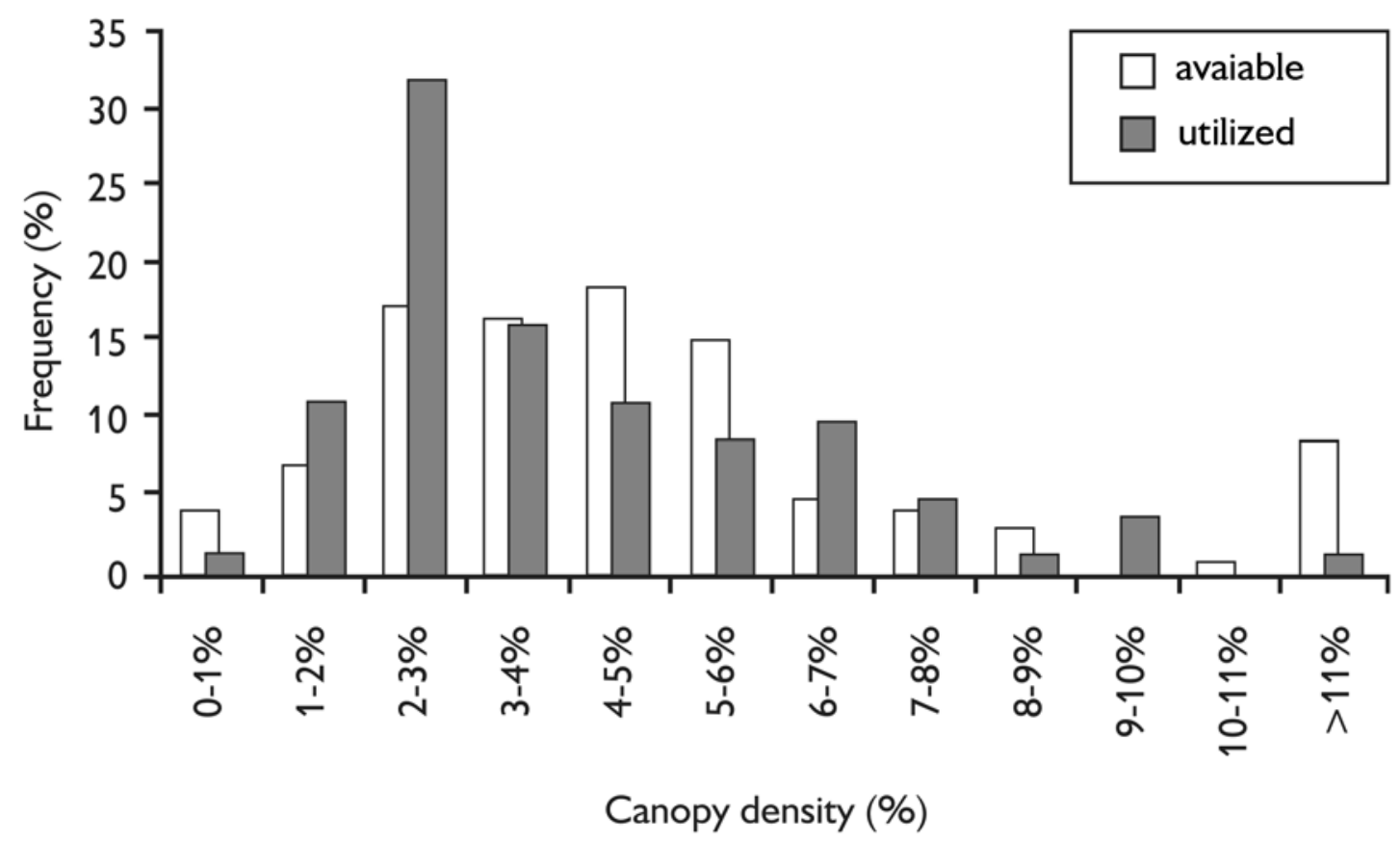

Figure 8. Percentage of canopy density above the trunks utilized by Gonatodes humeralis and above available trunks in the studied sites.

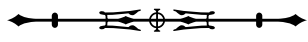


see predators. Similarly, several features in the environment around the trunk may be important in determinating the "quality" of trunks, such as canopy density above the trunk, that greatly affects the temperature and ilumination, and the amount of leaf litter around trunk, that may provide refuge, and, to a lesser degree, make movement between trunks and foraging easier. On the other hand, leaf litter may provide shelter to predators, etc. The presence of a thin layer of leaf litter around trunks utilized by $G$. humeralis may make predator detection easier. This species has been found in stomach contents of several species of snakes that prey in leaf litter. (Dixon \& Soini, 1975; Martins, 1991; Ávila-Pires, 1995). The data obtained show also the relation between the amount of leaf litter and the mean height of forest, suggesting that deforestation may be interfering positively in the populations of $G$. humeralis, providing ideal conditions in terms of both the amount of leaf litter and size of trunks that it exploits.

Preference for trunks of certain circumferences, suggested by Nunes (1984), was not observed in this study. Nevertheless, the majority of the lizards observed in this study was occupying trunks that had dimensions similar to those observed by Nunes (1984). Differences in the selection of these features may be associated with differences in the availability of trunks between the sampled forest areas in all these studies.

However, two features were utilized in different proportions relative to those available in the environment. The amount of leaf litter around available trunks was greater than around trunks used by $G$. humeralis $\left(D_{78,140}=0.17, P\right.$ $=0.04$ ) and the majority of individuals were encountered on trunks with bark of intermediate rugosity (for two trunks no data on rugosity are available) $\left(D_{78,138}=0.25, P=\right.$ $0.06)$. Gonatodes humeralis used mainly trunks surrounded by a layer of leaf litter 3.0 to $6.0 \mathrm{~cm}$ deep (Figure 9) and with a rugosity degree of 3 (Figure 10).

Regarding changes in forest structure relative to deforestation, the strong relation between the amount of leaf litter and the mean height of vegetation indicates that

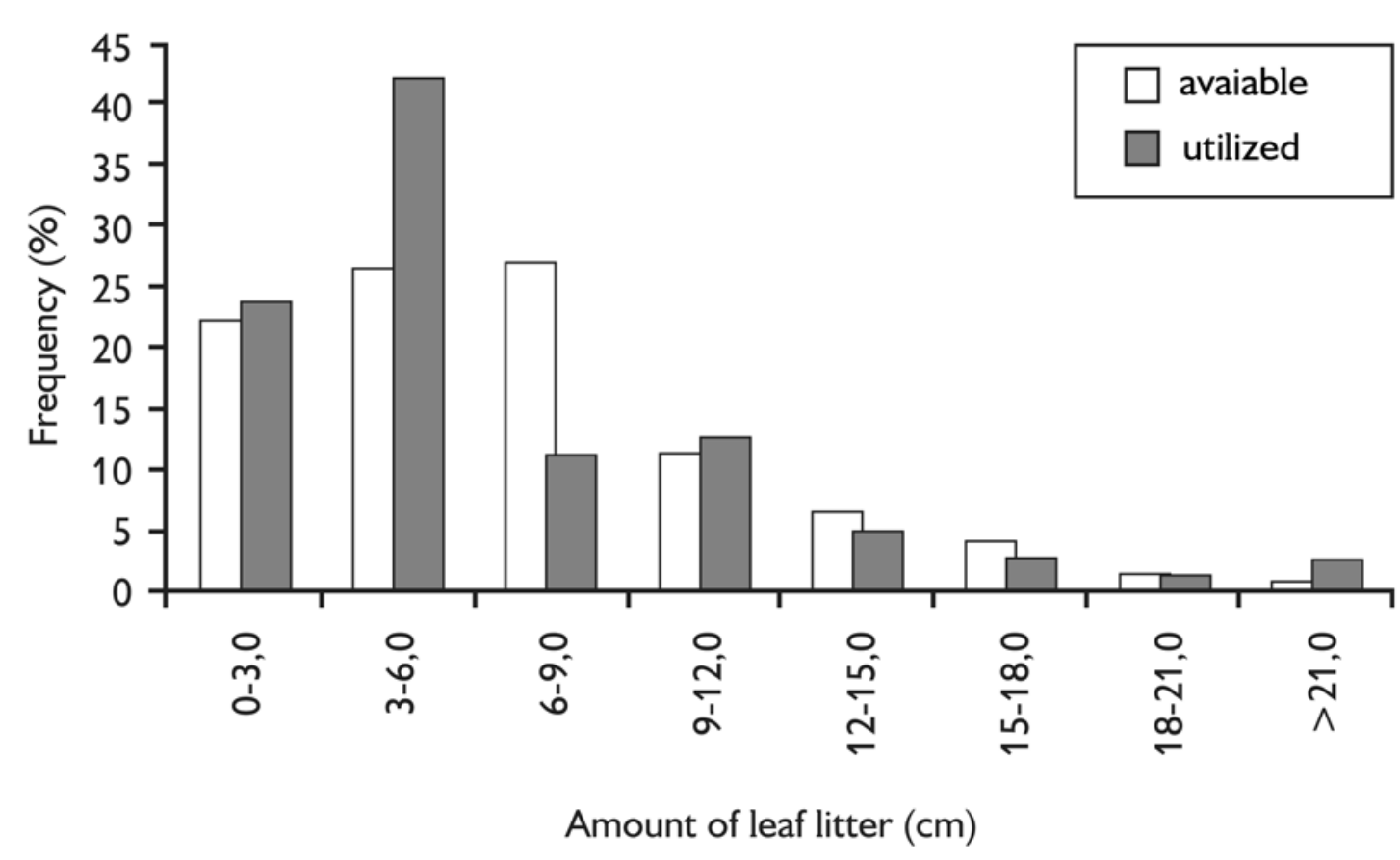

Figure 9. Amount of leaf litter around trunks utilized by $G$. humeralis and around trunks available at the forest in the studied sites.

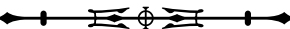




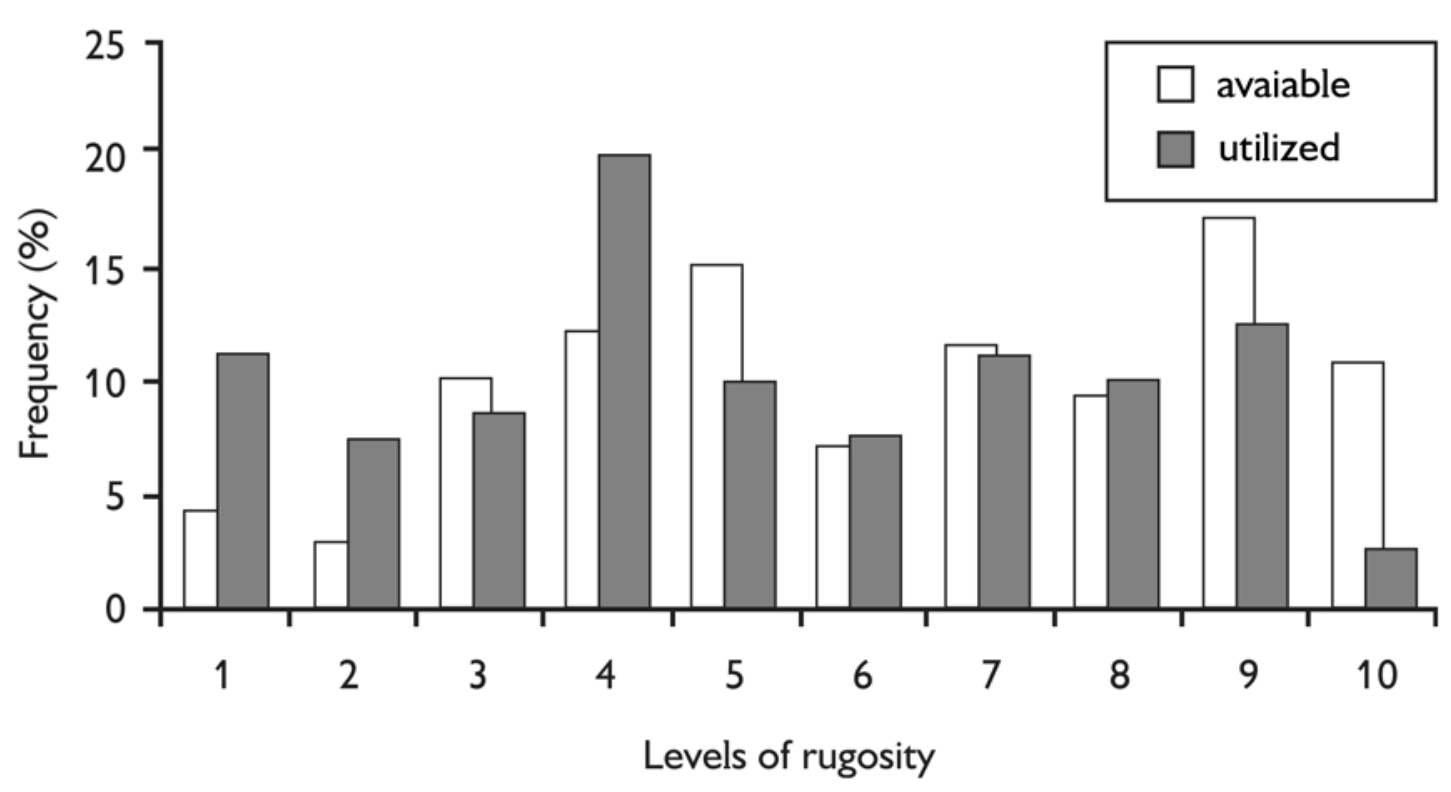

Figure 10. Surface rugosities of trunks utilized by Gonatodes humeralis and available trunks in the forest in the studied sites.

older forests possess a larger amount of leaf litter in the soil $\left(r^{2}=0.788, p=0.002, n=11\right)$.

Lower amount of leaf litter in younger forests may give some advantage to this species that seems to prefer a lower amount of leaf litter. Since this species walks frequently from one trunk to another (Vitt et al., 2000), dense leaf litter can hamper such displacements.

Trunk surface rugosity and regularity may be important for $G$. humeralis, because it occasionally moves rapidly around the trunks to hide from predators (Vanzolini, 1972). Very irregular surfaces may make this movement difficult, while very smooth surfaces may make it difficult to grip the trunk and stay in one place. Preference for trunks with intermediate rugosity suggests that $G$. humeralis is selecting trunks whose surfaces have sufficient rugosity to allow a solid grip and, at the same time, be sufficiently regular to permit its movement and detection of predators.

It is possible to conclude that in Manaus, the population density of Gonatodes humeralis changes after forest disturbances. These changes are associated to trunk density and regeneration time in each area. At the beginning of regeration a decrease in population density seems to occur due to reduction of tree species and consequently, in the density of available tree trunks. During subsequent periods, a gradual increase in population density occurs with the development of trees and bushes and consequent increase in trunks availability. In old secondary forests, population density declines to levels that are similar to the natural environment.

Regarding habitat utilization, the patterns found here are, in some aspects, different from those observed in other studies involving this species. These differences can be explained in part by the inclusion, in this study, of secondary forest areas, that possess very different features related to microhabitats availability. The results found here indicate that trunk circumference and canopy density are not important features in microhabitat selection by G. humeralis. However, the amount of leaf litter around trunks and the rugosity of trunk surfaces were utilized in different proportions than those available in nature, indicating that these features are important for the selection of trunks by this species. 


\section{ACKNOWLEDGMENTS}

I thank INPA, PDBFF, UFAM, SEDEMA e SESI for logistic support. Peter De Chant, Albertina Lima, William Magnusson, Claude Gascon, Ulisses Gallati, Luis Alberto Monjeló, Eduardo Venticinque, Marcelo Gordo, Flora Benetton and Ruth Alencar Peixoto for suggestions and comments. Ocírio Pereira, Odinéia Forner and Zenilda P. Oda helped to collect data.

\section{REFERENCES}

ÁVILA-PIRES, T. C. S., 1995. Lizards of Brazilian Amazonia (Reptilia: Squamata). Zoologische Verhandenlingen 299: 1-706.

BIERREGAARD, R., C. GASCON, T. E. LOVEJOY \& R. C. G. MESQUITA, 2001. Lessons from Amazonia. Yale University Press, New Haven, Connecticut.

CRUMP, M. L., 1971. Quantitative analysis of the ecological distribution of a tropical herpetofauna. Occasional Papers of the Museum of Natural History 3: 1-62.

CUNHA, O. R., F. P. NASCIMENTO \& T. C. S. ÁVILA-PIRES, 1985. Os répteis da área de Carajás, Pará, Brasil (Testudines e Squamata). Publicações Avulsas do Museu Paraense Emílio Goeldi 40: 9-92.

DIXON, J. R. \& P. SOINI, 1975. The reptiles of the upper Amazon Basin, Iquitos region, Peru. Milwaukee Public Museum, Contributions to Biology and Geology 4: 1-58.

DUELLMAN, W. E., 1987. Lizards in an Amazonian rain forest community: resource utilization and abundance. National Geographic Research 3: 489-500.

GASC, J. P., 1990. Les Lezards de Guyane: 1-76. Ed. Raymond Chabaud, Paris.

JOHNS, A. D., 1985. Selective logging and wildlife conservation in tropical rain forest: problems and recommendations. Biological Conservation 31: 355-375.
MARTINS, M., 1991. The lizards of Balbina, Central Amazonia, Brazil: a qualitative analysis of resource utilization. Studies on Neotropical Fauna and Environment 26: 179-190.

NUNES, V. S., 1984. Ciclo de atividade e utilização do habitat por Gonatodes humeralis (Sauria, Gekkonidae) em Manaus, Amazonas. Papéis Avulsos de Zoologia 35: 147-152.

O'SHEA, M., 1989. The herpetofauna of Ilha de Maracá, State of Roraima, Northern Brasil. In: J. COOTE (Ed.): Reptile: Proceedings of the 1988 U. K. Herpetological Societies Symposium on Captive Breeding: 51-72. British Herpetological Society, London.

RAND, A. S. \& S. S. HUMPHREY, 1968. Intespecific competition in the tropical rain forest: ecological distribution among lizards at Belém, Pará. Proceeding United States Natural History Museum 125: 1-17.

SCOTT JR., N. J., 1976. The choice of perch dimensions by lizards of the genus Anolis (Reptilia, Lacertilia, Iguanidae). Journal of Herpetology 10: 75-84.

VANZOLINI, P. E., 1986. Levantamento Herpetológico da área do estado de Rondônia sob influência da rodovia BR-364. Programa Polonoroeste, Subprograma Ecologia Animal, Relatório de Pesquisa $n^{\circ}$ 1: 1-150, MCT/CNPq, Brasília, Brasil.

VANZOLINI, P. E., 1972. Miscellaneous notes on the ecology of some Brazilian lizards (Sauria). Papéis Avulsos de Zoologia 26: 83-115.

VANZOLINI, P. E., 1968. Lagartos brasileiros da família Gekkonidae (Sauria). Arquivos de Zoologia 17: 1-84.

VITT, L. J., R. A. SOUZA, S. S. SARTORIUS, T. C. S. ÁVILA-PIRES \& M. C. ESPÓSITO, 2000. Comparative ecology of sympatric Gonatodes (Squamata: Gekkonidae) in the western Amazon of Brazil. Copeia 2000: 83-95.

VITT, L. J., P. A. ZANI \& A. A. M. BARROS, 1997. Ecological variation among populations of the gekkonid lizard Gonatodes humeralis in the Amazon Basin. Copeia 1997: 32-43.

Recebido: 30/01/2008 Aprovado: 02/11/2008 
